\title{
The effect of waaL genes deletion from Yersinia enterocolitica 0:3 genome on bacteria LPS' phenotype
}

\author{
J. I. Shevchenko ${ }^{1,2}$, V. K. Pozur ${ }^{1}$, M. Skurnik ${ }^{2}$ \\ ${ }^{1}$ Educational and Scientific Center «Institute of Biology» \\ Taras Shevchenko National University of Kyiv \\ 64/13, Volodymyrska Str., Kyiv, Ukraine, 01601 \\ ${ }^{2}$ Haartman Institute, University of Helsinki \\ Haartmaninkatu 3 (P. O. Box 21), Finland, FIN-00014 \\ julia.i.shevchenko@gmail.com
}

\begin{abstract}
Aim. To estimate WaaL ligase contribution in the lipopolysaccharide (LPS) phenotype profile formation of Y. enterocolitica O:3 (YeO3) bacteria. Methods. The waaL-knock-out mutants were created by an allelic exchange strategy. The LPS phenotypes of created mutants were visualized by silver-stained DOC-PAGE and immunoblotting with specific outer core (core oligosaccharide, hexasaccharide, OC) and O-polysaccharide (OPS or O-Ag) monoclonal antibodies. Results. Deletion of waa $L_{\text {os }}$ gene from YeO3 genome has a marked effect on OC ligation in either single or double mutants. The waa $L_{P S}$ deletion has an opposite effect on the OPS ligation - barely detected increasing of OPS bands. Conclusions. The LPS ligases of YeO3 exhibit relaxed donor substrate specificity. Under given conditions the effect of Waa $L_{\text {os }}$ ligase is more significant for OC and OPS ligation onto lipid A than that of WaaL $L_{P S}$
\end{abstract}

Keywords: WaaL ligase, LPS, Yersinia enterocolitica, DOC-PAGE.

Introduction. In Europe, yersiniosis is the third most common bacterial zoonosis after campylobacteriosis and salmonellosis [1]. Y. enterocolitica is a well known human and animal pathogen. Among humans, the pathway of $Y$. enterocolitica is associated with intestinal disease, such as enterocolitis, with inflammatory diarrhea, ileitis, mesenteric appendicitis and gastroenteritis. A diarrheal disease is sometimes followed by post-infectious reactive arthritis.

It is well known that all Gram-negative bacteria contain an outer leaflet with a large amount of lipopolysaccharide (LPS). LPS is a glycolipid consisting of three domains: the lipid A moiety, the core and the distal Opolysaccharide (OPS or $\mathrm{O}-\mathrm{Ag}$ ). The homopolymeric $\mathrm{O}$-Ag is composed of $\beta 1$,2-linked 6-deoxy-L-altrose residues. Together with the hexasaccharide core, the O$\mathrm{Ag}$ is linked to the inner core (IC) of LPS to form a branched structure [2]. The antigenic variations of OPS in the $Y$. enterocolitica isolates are distinguished serologi-

(C) Institute of Molecular Biology and Genetics, NAS of Ukraine, 2014 cally. Nowadays, more than 50 serotypes are known, of which $0: 3,0: 5,27,0: 8$ and $0: 9$ are pathogenic [3].

The LPS biosynthesis is a complex process that includes the stepwise transformation of the primary substrate under enzymatic treatment. The WaaL proteins are involved in the ligation of OC and O-Ag onto the lipid A core. According to the in silico investigations, the $Y$. enterocolitica $\mathrm{O}: 3(\mathrm{YeO} 3)$ genome contains at least three genes responsible for the WaaL proteins expression. Yersinia pestis and Yersinia pseudotuberculosis, however, carry only the $w a a L_{\mathrm{PS}}$ gene, whereas either $w a a L_{\mathrm{OS}}$ or $w a a L_{\mathrm{XS}}$ or both are additionally present in other Yersinia species.

It was shown that deletion of $w a a L_{\mathrm{OS}}$ and $w a a L_{\mathrm{PS}}$ genes correlate with the OPS and the OC expression. For this purpose LPS ligases were named as $\mathrm{WaaL}_{\mathrm{PS}}$ and $\mathrm{WaaL}_{\mathrm{OS}}$ respectively. The third ligase named as $\mathrm{WaaL}_{\mathrm{Xs}}$ was not involved in the LPS or ESA biosynthesis [4].

The current study is aimed at the estimation of a role of the ligases in the Y. enterocolitica' LPS phenotype profile formation. The waaL-knock-out mutants of $\mathrm{YeO} 3$ 


\begin{tabular}{|c|c|c|}
\hline Strain & Genotype & Reference \\
\hline \multicolumn{3}{|c|}{ Yersinia enterocolitica } \\
\hline $6471 / 76$ & YeO3 wild type strain, patient isolate & {$[6]$} \\
\hline $6471 / 76-c$ & YeO3-c virulence plasmid cured derivative of $6471 / 76$ & {$[6]$} \\
\hline YeO3_Aos & waaL $_{\mathrm{OS}}:: \mathrm{pSW} 23 \mathrm{Tlig} 1727 \mathrm{su}$ & This work \\
\hline YeO3_sps & waaL $_{\mathrm{PS}}:: \mathrm{pSW} 29-$ lig532del, $\mathrm{Km}^{\mathrm{R}}$ & This work \\
\hline YeO3_dos_dps & 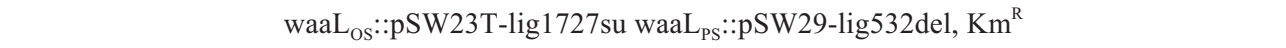 & This work \\
\hline \multicolumn{3}{|c|}{ Escherichia coli } \\
\hline$\omega 7249$ & $\mathrm{~B} 2163 \Lambda$ nic $35, E$. coli strain for suiside vector delivery, requirement for diaminopimelic acid $0.3 \mathrm{mM}^{\mathrm{K}} \mathrm{Km}^{\mathrm{R}}$ & [7] \\
\hline S17-1 pir & A-pir lysogen of S17-1, E. coli strain for suiside vector delivery & {$[8]$} \\
\hline DH10B & 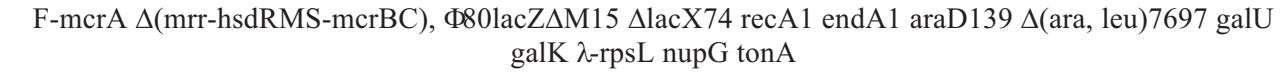 & $\begin{array}{l}\text { Life Tech- } \\
\text { nologies }\end{array}$ \\
\hline
\end{tabular}

were created by the allelic exchange strategy. Phenotypes of created mutants were visualized by silver-stained DOC-PAGE and immunoblotting with specific OC and $\mathrm{O}-\mathrm{Ag}$ monoclonal antibodies.

Materials and methods. Bacterial strains and culture conditions. Bacterial strains are listed in Table. Yersinia strains were grown at $22-25^{\circ} \mathrm{C}(\mathrm{RT})$ and $E s$ cherichia coli strains at $37^{\circ} \mathrm{C}$ in Luria Broth (LB) media. LB supplemented with $1.5 \%$ Bacto Agar was used for all solid cultures. As a selective medium CIN agar supplemented with appropriate antibiotics was used. When appropriate, the antibiotics were added to the media at the following concentrations: kanamycin $(\mathrm{Km})$, $100 \mu \mathrm{g} / \mathrm{ml}$ in agar plates and $20 \mu \mathrm{g} / \mathrm{ml}$ in broth; chloramphenicol $(\mathrm{Clm}), 20 \mu \mathrm{g} / \mathrm{ml}$.

General DNA techniques. Isolation of plasmids and genomic DNA was done with kits. All enzymes were used according to the supplier's specifications. Smallscale plasmid DNA preparations were carried out using plasmid mini prep kits. Plasmid DNA was moved by electroporation into $Y$. enterocolitica or heat shock transformation. Recombinant plasmids were mobilized from E. coli strains to $Y$. enterocolitica by conjugation.

Mutants construction. The $w a a L_{\mathrm{OS}}$ and $w a a L_{\mathrm{PS}}$ genes were amplified by PCR with primer pairs O3lig YE1727F5 \& O3ligYE1727R5 and O3ligYE532F2 \& O3ligYE532R2 with DyNAzyme DNA-polymerase («Thermo Scientific», USA) from isolated genomical DNA of YeO3. Amplified DNA was purified with Kit method and digested with NsiI (Mph 1103I) for the $w a a L_{\mathrm{OS}}$ gene and PstI for $w a a L_{\mathrm{PS}}$. The digested and purified fragments were cloned into the PstI digested suicide vector $p S W 23 T$ and the constructed plasmids were named as $p S W 23 T$-waa $L_{\mathrm{OS}}$ and $p S W 23 T$-waa $L_{\mathrm{PS}}$ respectively. The constructions were mobilized from $E$. coli $\omega 7249$ into $\mathrm{YeO} 3$ strains by conjugation as described earlier [5]. For elimination of suicide vector and the wildtype genes, the optimized cycloserine enrichment method was used [5].

For large-scale screening of knock-out mutants among Clm sensitive bacteria $\left(\mathrm{Clm}^{\mathrm{s}}\right)$ colonies we used Colony hybridization kit method («Roche», France). Isolated genomical DNA from negative colonies were diluted and used as a template for PCR with different primer pairs. DNA of wild-type strain $\mathrm{YeO} 3$ was used as a control.

Complementation. The $w a a L_{\mathrm{OS}}$ and $w a a L_{\mathrm{PS}}$ genes were amplified with Phusion DNA polymerase from YeO3-c with O3ligYe1727f \& O3ligYe1727r, O3lig Ye532f \& O3ligYe532r primer pairs. PCR fragments were phosphorylated with polynucleotide kinase in the presence of $10 \mathrm{mM}$ ATP, digested with EcoRI and ligated with EcoRI and ScaI digested, SAP-treated pTM100. The constructed plasmids were named pEPlig 1727 \& pEPlig532 and electroporated into S17-1 $\lambda$ pir with further mobilization into $\mathrm{YeO} 3$ ligase mutants by conjugation. Obtained colonies were screened on appropriate antibiotic plates with CIN agar [4]. 

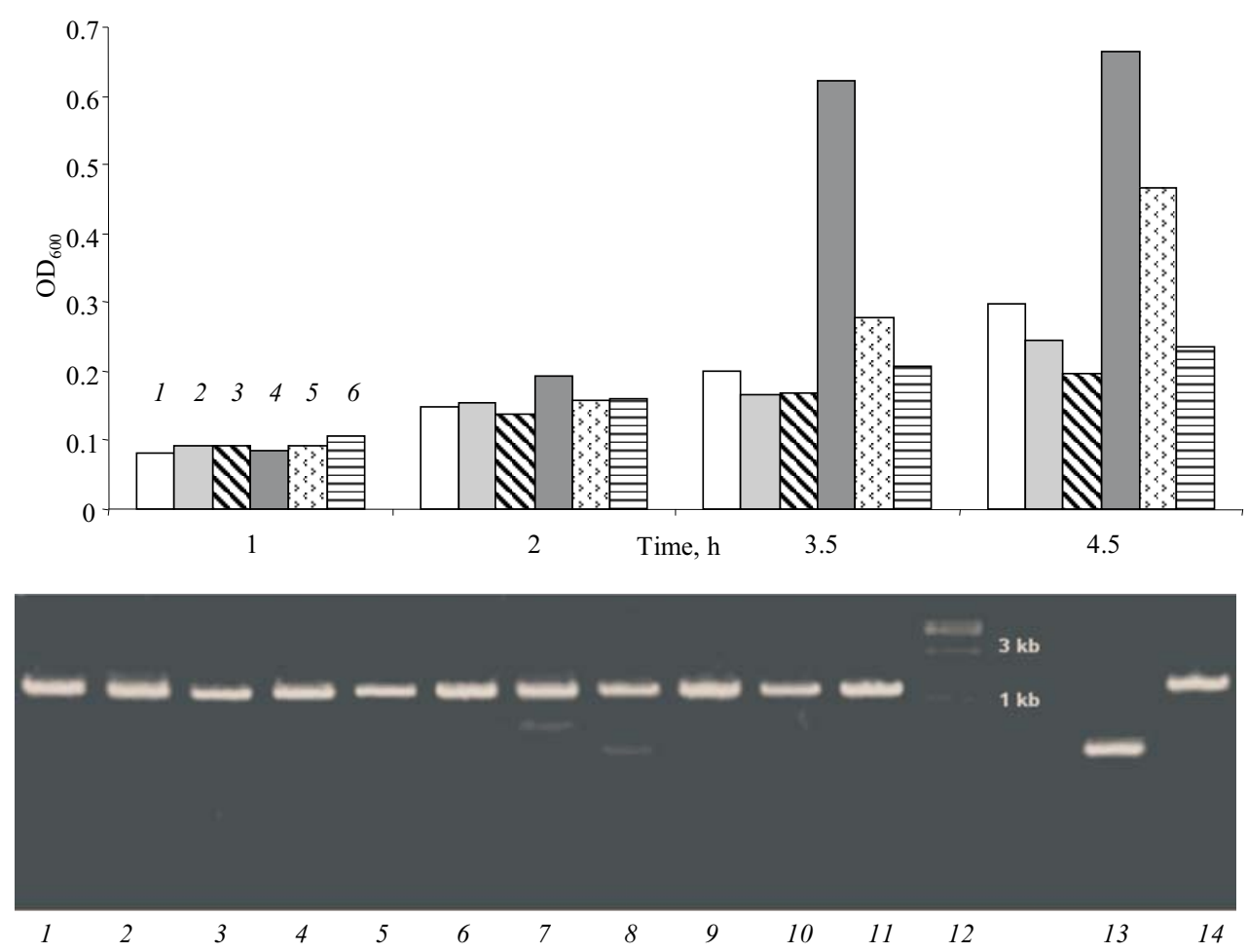

Fig. 1. Optimization of cycloserine enrichment method: $1-\mathrm{YeO} 3$ wild type (WT), $2.5 \mu 1 \mathrm{v} / \mathrm{v} ; 2-\mathrm{WT}, 5 \mu 1 \mathrm{v} / \mathrm{v}$; $3-\mathrm{WT}, 10 \mu \mathrm{v} / \mathrm{v} ; 4-$ merodiploids (MD), $2.5 \mu 1 \mathrm{v} / \mathrm{v} ; 5-\mathrm{MD}, 5 \mu 1 \mathrm{v} / \mathrm{v} ; 6-$ $\mathrm{MD}, 10 \mu \mathrm{v} / \mathrm{v}$
DOC-PAGE analysis. The bacteria were grown 16$20 \mathrm{~h}$ at RT in $5 \mathrm{ml}$ of LB medium with appropriate antibiotics. The exact optical density of the cultures was measured at $600 \mathrm{~nm}\left(\mathrm{OD}_{600}\right), 3 \mathrm{ml}$ of the cultures were centrifuged and the pellets were resuspended in deoxycholate lysis buffer (2\% DOC, $4 \%$ 2-mercaptoethanol, $10 \%$ glycerol and $0.002 \%$ bromophenol blue in $1 \mathrm{M}$ Tris-HCl buffer, $\mathrm{pH}$ 6.8) in a volume adjusted according to density of the culture $\left(100 \mu \mathrm{l} / \mathrm{OD}_{600} \sim 1\right)$. Lypopolysaccaride phenotypes were analyzed by silver stained DOC-PAGE with previous proteinase $\mathrm{K}$ treated whole cell lysates [4]. The Western blotting O-polysaccharide, outer core and inner core expression were detected by O:3 specific mAbs 2B5 and TomA6.

Results and discussion. Mutants construction. The $w a a L_{\mathrm{OS}}$ and $w a a L_{\mathrm{PS}}$ mutants of $\mathrm{YeO} 3$ were constructed from fully virulent serotype $0: 3$ patient isolate expressing complete LPS. With help of the allelic exchange strategy we managed to inactivate $w a a L_{\mathrm{OS}}$ and $w a a L_{\mathrm{PS}}$ encoding regions in the $\mathrm{YeO} 3$ genome. The constructed single and double mutants were complemented with the pEPlig $1727 \&$ pEPlig532 plasmids, which were supplemented with the functional waaL gene.

Traditional cycloserine enrichment method was additionally optimized [5]. The possibility was conside- red that constructed merodiploids (MD) are not fully resistant to Clm, as it should be (weak operon, etc.). To examine this possibility we tested several lines of conditions (concentration of $\mathrm{Clm}$, incubation time, density of bacteria, etc.). According to these experimental data, the next improvements were done: reducing the $\mathrm{Clm}$ concentration in media to $2.5 \mu \mathrm{v} / \mathrm{v}$ (instead of $10 \mu \mathrm{l} \mathrm{v} / \mathrm{v}$ ) and prolongation of incubation to 4-5 h (instead of 2-3 h) before D-cycloserition solution was added. A current modification of the method allowed us to pick up only bacteria after second crossing over (Fig. 1).

The colony hybridization method was used for specific detection of deletion in the waaL gene among $\mathrm{Clm}^{\mathrm{s}}$. Further justifications of deletion were performed by PCR (Fig. 2).

Phenotype analysis. We used two approaches to analyze the difference in the expression of OC and OAg: 1) Silver staining of DOC-PAGE; 2) Immunoblotting with $\mathrm{OC}$ and $\mathrm{O}-\mathrm{Ag}$ specific antibodies.

It is noticeable from silver staining of DOC-PAGE that deletion in the $w a a L_{\text {OS }}$ gene leads to a dramatic decrease in the OC expression and appearance of strong IC band (Fig. 3). However, the level of O-Ag expression reduced, as well, compared to the mutant with deletion in the $w a a L_{\mathrm{PS}}$ gene. The deletion in the $w a a L_{\mathrm{PS}}$ gene 


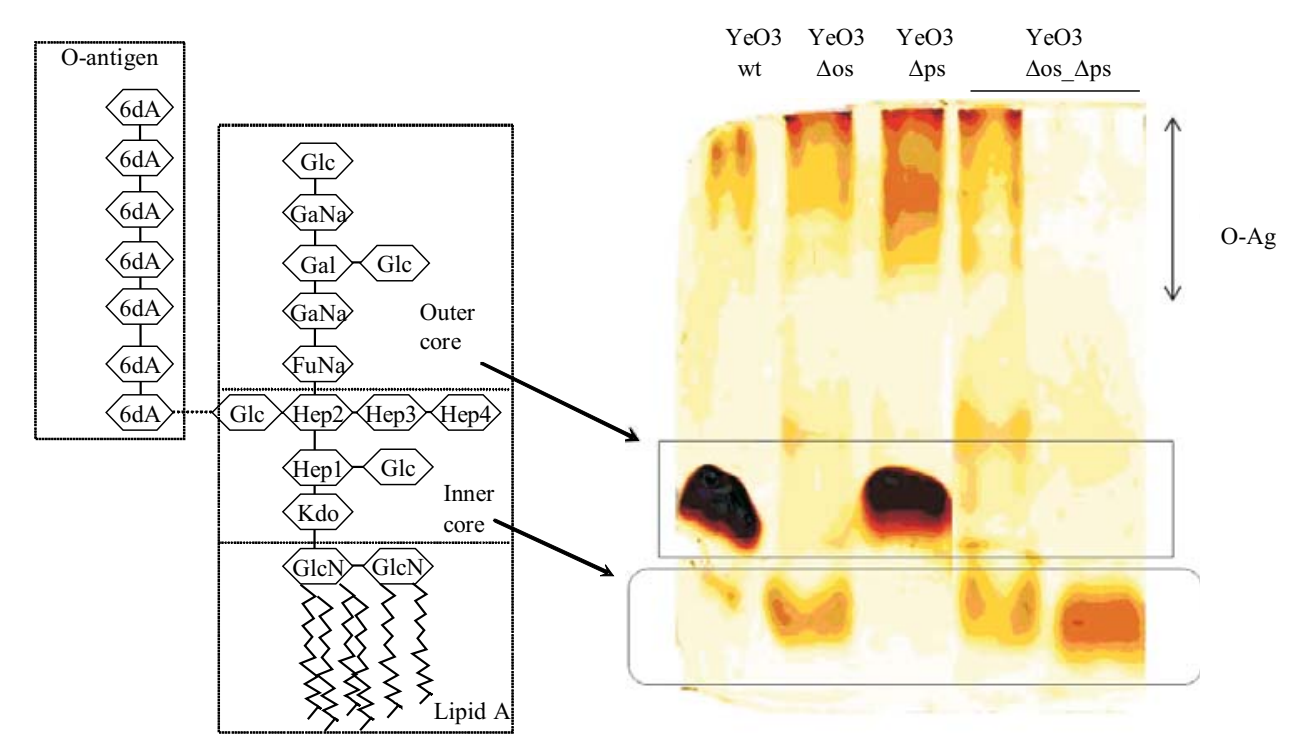

Fig. 3. Silver-stained DOC-PAGE analysis of LPS phenotypes of different ligase mutants

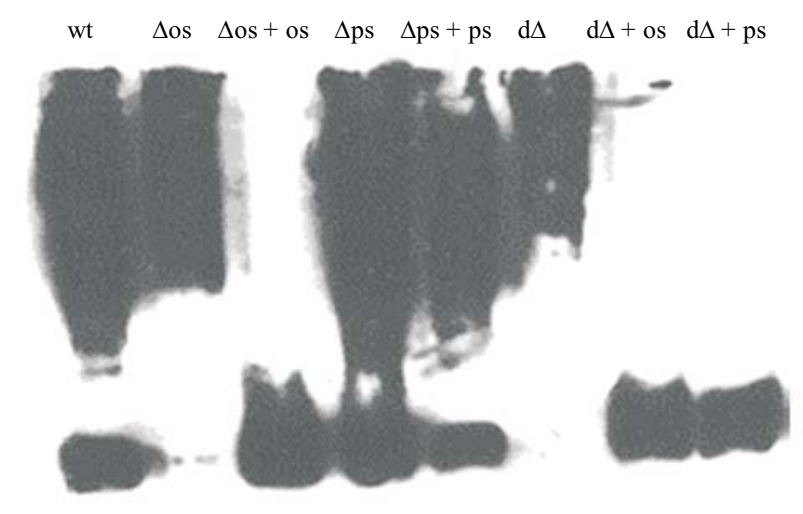

Fig. 4. Immunoblot analysis of LPS phenotypes of waaL mutants of $\mathrm{YeO} 3$. DOC-PAGE membrane was probed with $\mathrm{mAb} 2 \mathrm{~B} 5$ and TomA6

seems to be insignificant for the OC expression and even to stimulate the OPS formation. In case of the double $\mathrm{YeO} 3 \_\Delta$ os_sps mutants, it is noticeable a strong expression of IC bands, the absence of OC in both variants and the absence of O-Ag expression in one variant.

Western blotting analysis of LPS samples of the $\mathrm{YeO} 3$ ligase mutants and their complementation of single and double mutants were performed with the OCspecific $\mathrm{mAb} 2 \mathrm{~B} 5$ and $\mathrm{O}-\mathrm{Ag}$-specific mAb TomA6 (Fig. 4). The deletion in the $w a a L_{\mathrm{OS}}$ gene resulted in reduction of the OC expression, as it was shown with silver staining of DOC-PAGE. Also, the $w a a L_{\mathrm{OS}}$-knockout mutant complemented with the functional waa $L_{\mathrm{OS}}$ gene showed full recovery of $\mathrm{OC}$ and the decreasing of $\mathrm{O}-\mathrm{Ag}$ expression at the same time.
Similar results were obtained with the double mutant and complementation variants. The LPS profile of

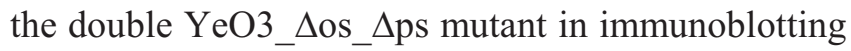
was similar to that with silver staining where only the $\mathrm{O}-\mathrm{Ag}$ expression took place. The complementation with the functional $w a a L_{\mathrm{OS}}$ and $w a a L_{\mathrm{PS}}$ genes showed inhibition of O-Ag expression and full recovery of OC in both cases. Disruption in the $w a a L_{\mathrm{PS}}$ gene as a single mutation leads to hardly noticeable stimulation of the $\mathrm{O}-\mathrm{Ag}$ expression.

Thereby, the data obtained from silver staining and immunoblotting of DOC-PAGE evidence the participation of WaaL ligase in the LPS phenotype creation. However, strict substrate specificity of the LPS ligase in $\mathrm{YeO} 3$ was not detected.

Conclusions. Summarizing the obtained data we can conclude that the LPS ligases of $\mathrm{YeO} 3$ exhibit relaxed donor substrate specificity. It has been established that under given conditions the effect of the $\mathrm{WaaL}_{\mathrm{OS}}$ ligase is more significant for the OC and OPS ligation onto lipid $\mathrm{A}$ than for the $\mathrm{WaaL}_{\mathrm{PS}}$ ligase. It is possible that deletion of the $w a a L_{\mathrm{OS}}$ and $w a a L_{\mathrm{PS}}$ genes and changes in the OC or O-Ag moieties of LPS enhance the ability of pathogen to evade host defenses. Further work is required to elucidate the biological significance of these different settings.

Funding. This work was supported by grants from Center for International Mobility (CIMO), Finland TM-12-8286. 
Вплив делецій генів лігаз waaL на фенотип ліпополісахаридів у бактерій Yersinia enterocolitica $\mathrm{O}: 3$

\section{Ю. І. Шевченко, В. К. Позур, М. Скурник}

\section{Резюме}

Мета. Дослідити участь лігаз WaaL у формуванні фенотипу ліпополісахариду (LPS) серед бактерій Y. enterocolitica O:3 (YеO3). Методи. Нокаутні мутанти по генах лігаз жаaL створено внаслідок обміну алелями. Фенотипи LPS отриманих мутантів візуалізували, забарвлюючи сріблом гель DOC-PAGE, а також використовували імуноблот зі специфічними моноклональними антитілами до кору (корового олігосахариду, гексасахариду, ОС) та $O$ полісахариду (OPS, O-Ag). Результати. Делеиія гена лігази waaL з геному бактерій ҮеО3 чинить помітний вплив на лігування ОС як в одиночних, так $і$ в подвійних мутантах. Проте маніпуляиії з геном лігази жаaLPS призводять до ледь помітної стимуляиії утворення OPS. Висновки. Лігази LPS бактерій ҮеО3 демонструють низьку субстратну специфічність. Участь лігази $\mathrm{WaaL}_{O S} y$ формуванні повночінної структури LPS є суттєвішою, аніж WaaLPS, за даних умов.

Ключові слова: лігази WaaL, LPS, Yersinia enterocolitica, DOC$P A G E$.

Влияние делеций генов лигаз waaL на фенотип

липополисахаридов у бактерий Yersinia enterocolitica $\mathrm{O}: 3$

\section{Ю. И. Шевченко, В. К. Позур, М. Скурник}

\section{Резюме}

Цель. Исследовать участие лигаз WaaL в формировании фенотипа липополисахарида (LPS) среди бактерий Y. enterocolitica O:3 (YеO3). Методы. Нокаутные мутанты по генам лигаз waаL coзданы вследствие обмена аллелями. Фенотипь LPS полученных мутантов визуализировали, окрашивая серебром гель DOC-PAGE, а также с использованием иммуноблота со специфическими моноклональными антителами к кору (коровому олигосахариду, гексасахариду, ОС) и О-полисахариду (OPS, O-Ag). Результаты. Делеция гена лигазы waаL ${ }_{O S}$ из генома бактерий YеОЗ оказывает заметное влияние на лигирование ОС как в одиночных, так и двойных мутантах. Однако манипуляции с геном лигаз waa $_{P S}$ приводят кедва заметной стимуляции образования OPS. Выводы. Ли- газы LPS бактерий ҮеОЗ демонстрируют низкую субстратную специфичность. Участие лигазы $\mathrm{WaaL}_{\mathrm{OS}}$ в образовании полноиенной структуры LPS является более существенным, чем WaaLPS, при данных условиях.

Ключевые слова: лигазы WaaL, LPS, Yersinia enterocolitica, DOC$P A G E$.

\section{REFERENCES}

1. Ortiz Martinez P, Mylona S, Drake I, Fredriksson-Ahomaa M, Korkeala H, Corry JE. Wide variety of bioserotypes of enteropathogenic Yersinia in tonsils of English pigs at slaughter. Int $J$ Food Microbiol. 2010;139(1-2):64-9.

2. Skurnik M, Venho R, Toivanen P, al-Hendy A. A novel locus of Yersinia enterocolitica serotype O:3 involved in lipopolysaccharide outer core biosynthesis. Mol Microbiol. 1995;17(3):575-94.

3. Sabina $Y$, Rahman A, Ray RC, Montet D. Yersinia enterocoliti$c a$ : mode of transmission, molecular insights of virulence, and pathogenesis of infection. J Pathog. 2011;2011:429069.

4. Pinta E, Li Z, Batzilla J, et al. Identification of three oligo-polysaccharide-specific ligases in Yersinia enterocolitica. Mol Microbiol. 2012;83(1):125-36.

5. Biedzka-Sarek M, Venho R, Skurnik M. Role of YadA, Ail, and lipopolysaccharide in serumresistance of Yersinia enterocolitica serotype O:3. Infect Immun. 2005;73(4):2232-44.

6. Skurnik M. Lack of correlation between the presence of plasmids and fimbriae in Yersinia enterocolitica and Yersinia pseudotuberculosis. J Appl Bacteriol. 1984;56(3):355-63.

7. Babic A, Guerout AM, Mazel D. Construction of an improved RP4 (RK2)-based conjugative system. Res Microbiol. 2008;159(78):545-9.

8. Wilson KJ, Sessitsch A, Corbo JC, Giller KE, Akkermans AD, Jefferson RA. beta-Glucuronidase (GUS) transposons for ecological and genetic studies of rhizobia and other gram-negative bacteria. Microbiology. 1995;141 (Pt 7):1691-705.

Received 11.07.14 